原著論文

\title{
透析施設における補助犬使用者の受け入れ状況
}

\author{
三浦 靖史 ${ }^{1,2)}$ 、小林 彩恵子 2)、上田 麻紗子 2)、岸本 美穂 2)、橋本 裕美 2)、 \\ 今田 泰裕 ${ }^{2)}$ 、藤井 貴広 ${ }^{2)}$ 、大槻 史奈 ${ }^{2)}$ 、豊田 行健 ${ }^{2)}$ 、石川 智昭 ${ }^{1)}$ \\ 1）神戸大学大学院保健学研究科リハビリテーション科学領域 \\ 2) 神戸大学医学部保健学科
}

\section{A Survey of Circumstances Regarding Service Dog Users in Dialysis Facilities}

Yasushi Miura ${ }^{1,2)}$, Saeko Kobayashi ${ }^{2}$, Masako Ueda ${ }^{2)}$, Miho Kishimoto ${ }^{2)}$, Hiromi Hashimoto ${ }^{2)}$,

Yasuhiro Imada ${ }^{2)}$, Takahiro Fujii ${ }^{2)}$, Fumina Otsuki ${ }^{2)}$, Yukihiro Toyota ${ }^{2)}$, and Tomoaki Ishikawa ${ }^{1)}$

1) Department of Rehabilitation Science, Kobe University Graduate School of Health Sciences

2) Faculty of Health Sciences, Kobe University School of Medicine

\section{抄 録}

背景 : 2011 年に実施した病院に打ける補助犬の受け入れ状況に関する調査で、兵庫県の 2 病院から透析 室に補助犬を同伴可能であるとの回答があった。そこで、本調査では、透析施設における補助犬使用者の 受け入れの現状を調査し、受け入れに関する課題について検討した。

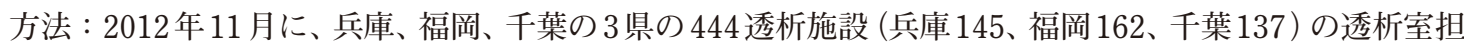
当看護師長を対象に、補助犬に関するアンケート調査を郵送で実施した。

結果: 回収率は $62.4 \%$ (277施設) であった。補助犬利用者を受け入れたことがある透析施設は $3.6 \%(10$ 施設）で、うち 6 施設では透析室のベットサイドに補助犬を同伴可能であった。地域別では、兵庫 4 施設

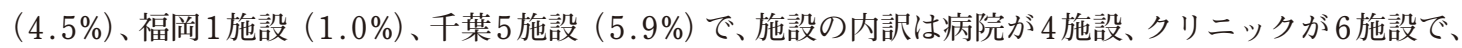
受け入れたことがある補助犬は全て盲導犬であった。マニュアルを使用していたのは全体の $1.8 \%$ （5施 設)、話し合いを行っていたのは $5.4 \%$ (15施設) で、89.2\%（247施設）では補助犬使用者の来院を想定 した準備を実施していなかった。身体障害者補助犬法の認知度は 54.1\%（150施設）であった。

考察 : 限られた施設数ではあるが、透析室のべッドサイドに補助犬を同伴して透析を受けることができ る施設が存在することが明らかになった。また、同伴された補助犬は全て盲導犬であったことから、網膜 症と腎症を併発している糖尿病患者が盲導犬を使用して透析施設に通院していることが考えられた。

結論 : 透析施設を含む全ての医療機関に扎いて、補助犬使用者の受け入れ対策を積極的に実施する必要 がある。

キーワード : 補助犬、身体障害者補助犬法、血液透析、リハビリテーション、バリアフリー

\footnotetext{
Abstract

Objective: We reported that two hospitals in Hyogo Prefecture accommodated service dogs in the dialysis facilities according to the survey in 2011. In this study we therefore surveyed the circumstances relating to service dogs in dialysis facilities.

Method: Questionnaires were sent out to the head nurses at 444 dialysis facilities in three prefectures (145 in Hyogo, 162 in Fukuoka, and 137 in Chiba) in November 2012.

Results: Collection rate was $62.4 \%$ (277 facilities). Ten dialysis facilities (3.6\%) had experienced visits of service dog users, and six of them allowed service dogs at the bedside. By region, 4 facilities were located in Hyogo (4.6\%), 1 in Fukuoka (1.0\%), and 5 in Chiba (5.7\%). By category, 4 facilities were hospitals and 6 were clinics. All the service dogs reported were guide dogs. Only 1.8\% (5 facilities) had compiled a manual and $5.4 \%$ (15 facilities) had discussed the acceptance of service dogs. In contrast,
} 
89.2\% (247 facilities) had never prepared for a possible service dog visit. The law concerning assistance dogs for the disabled was acknowledged in 54.1\% (150 facilities).

Discussion: It was found that a handful of dialysis facilities accepted service dogs at the bedside. Retinopathy and nephropathy associated with diabetes mellitus may be a reason why all the service dogs reported were guide dogs.

Conclusion: All medical facilities including dialysis facilities should prepare for the visits of service dog users proactively.

Keywords : service dogs, law concerning assistance dogs for the disabled, hemodialysis, rehabilitation, accessibility 


\section{I . 序論}

身体障害者補助犬 (以下、補助犬) は、身体障害者の自 立と社会参加に役立つ生きた自助具である。補助犬を使 用する身体障害者の施設等の利用の円滑化を図った身体 障害者補助犬法 (以下、補助犬法) が 2002 年 10 月に施行 されて約 11 年が経過したが、補助犬と補助犬法は十分に 社会で認知されて打らず、補助犬法で受け入れ義務が課 されている公共施設や公共交通機関、医療機関1)に打い ても補助犬の受け入れを拒否された事案が未だに報告さ れている2)。

これまでに我々は、2008年秋に兵庫県の病院を対象と した補助犬の受け入れ状況調査 ${ }^{3)}$ と、2011年秋に病院で の補助犬の受け入れ状況の兵庫県と福岡県との比較調查 4）及び、兵庫県に扎ける 3 年間での経時的変化の調査 ${ }^{4}$ を実施した。その結果から、補助犬利用者の病院への来 院は増加しており、医療従事者は受け入れに不安に感じ ていたが、実際の受け入れに際して大きな問題は生じて 抢らず、一方で、 $2 / 3$ の病院は補助犬使用者の来院を想 定した準備を行っていなかったことから、予準備をし ておくことにより不安なく受け入れができると考えられ た $^{4)}$ 。また、2011年の調査で、透析室へ補助犬を同伴で きる病院が $1.6 \%$ (兵庫県の 2 病院）存在することが明ら かとなった ${ }^{4)}$ 。

医療機関は、身体に障害を有する補助犬使用者にとっ て体調管理や疾病治療のために利用することが必須な施 設であるが、特に人工透析を実施している腎不全の患者 は、通常週に 3 回、定期的に透析施設に通院する必要が あり、補助犬使用者が補助犬を同伴して通院できるかは 重要な意義を持つ。

そこで、本研究では、透析施設に打ける補助犬利用者 の受け入れ状況を、近畿、九州、関東の各地区に打いて、 人口規模と透析施設数がほぼ同程度である兵庫県（人口 $5,588,133$ 人 $^{5)}$ 、 145 施設)、福岡県 (人口 $5,071,968$ 人) 162 施設)、千葉県 (人口 $6,216,289$ 人 $^{5}$ 、 137 施設) の透 析施設に対して、アンケート調査を実施することにより、 透析施設に打ける補助犬利用者の受け入れにおける課題 を明らかにして、透析施設を含む医療機関に打ける円滑 な補助犬受け入れを促進するための方法について検討し た。

\section{II. 方法}

\section{1. 調査期間、調查対象および倫理的配慮}

表 1 兵庫県、福岡県、千葉県の人口、補助犬数、透析施設数、 アンケート回答率

\begin{tabular}{|c|c|c|c|c|}
\hline & 兵庫県 & 福岡県 & 千葉県 & 合計 \\
\hline \multirow[t]{3}{*}{ 人口(推計) } & $5,588,133$ 人 & $5,071,968$ 人 & 6,216,289人 & \\
\hline & & N.S. & & \\
\hline & $P<0.01$ & $P<0.05$ & & \\
\hline 補助犬数 & 62頭 & 26頭 & 40 頭 & 128頭 \\
\hline 「盲導犬 & 「56頭 & 「 24頭 & 36頭 & 116頭 \\
\hline 介助犬 & 5頭 & 1頭 & 2頭 & 8頭 \\
\hline L 聴導犬 & L 1頭 & L $\quad 0$ 頭 & 2頭 & 3頭 \\
\hline 透析施設数 & 145施設 & 162施設 & 137施設 & 444施設 \\
\hline $\begin{array}{l}\text { アンケート回答率 } \\
\text { (回答数) }\end{array}$ & $\begin{array}{l}61.4 \% \\
(89 \text { 施設) }\end{array}$ & $\begin{array}{l}63.6 \% \\
(103 \text { 施設) }\end{array}$ & $\begin{array}{l}62.0 \% \\
(85 \text { 施設) }\end{array}$ & $\begin{array}{l}62.4 \% \\
(277 \text { 施設) }\end{array}$ \\
\hline
\end{tabular}

2012 年 11 月の 1 ケ間に、透析施設に対して郵送に よるアンケート調査を実施した。調査対象は、2010年 度版日本透析医学会施設会員名簿 ${ }^{6)}$ に記載された、兵庫 145 施設、福岡 162 施設、千葉 137 施設の合計 444 施設と した。回答者は、看護部長あるいは外来看護師長に依頼 した従来の調査と異なり ${ }^{3,4)}$ 、透析室内の状況を最も良 く把握していると考えられる透析室担当看護師長に依頼 した。アンケートは回答者名と施設名については無記名 として、全体の結果のみを解析して個々の施設について の解析や公表を行わないことを明記した上で、アンケー 卜参加への同意が得られる場合に返送を依頼した。

\section{2. 調査内容及び解析方法}

2008年及び2011年に実施した医療機関に打ける補助 犬受け入れ状況調査 ${ }^{3,4)}$ を基本として、透析中の補助犬 の待機場所に関する質問項目などの変更を加えて、医療 機関を対象とした 19 項目と、回答者個人を対象とした 5 項目の計 24 項目について、主に選択回答方式による質問 を行った (表 1$)$ 。アンケートの回答を集計し、群間での 相違についてはピアソンのカイ二乗独立性の検定を用い て検討した。

\section{III. 結果}

\section{1. 調査対象 3 県の背景}

2012 年 11 月の調査時点で、兵庫、福岡、千葉の 3 県の

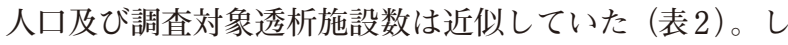
かし、補助犬数は、兵庫 62 頭、福岡 25 頭、千葉 40 頭であ $り^{7)}$ 、施設当たりの補助犬数は兵庫と千葉では有意差は なかったが、兵庫、千葉ともに福岡より有意に多かった (表 2)。アンケートを依頼した 3 県の 444 の透析施設の うち 277 施設から回答があり (回答率 $62.4 \%$ )、県による 回答率の相違を認めなかった (表 2 )。

\section{2. 補助犬使用者の透析施設への来院状況}


表2 アンケートの質問項目一覧

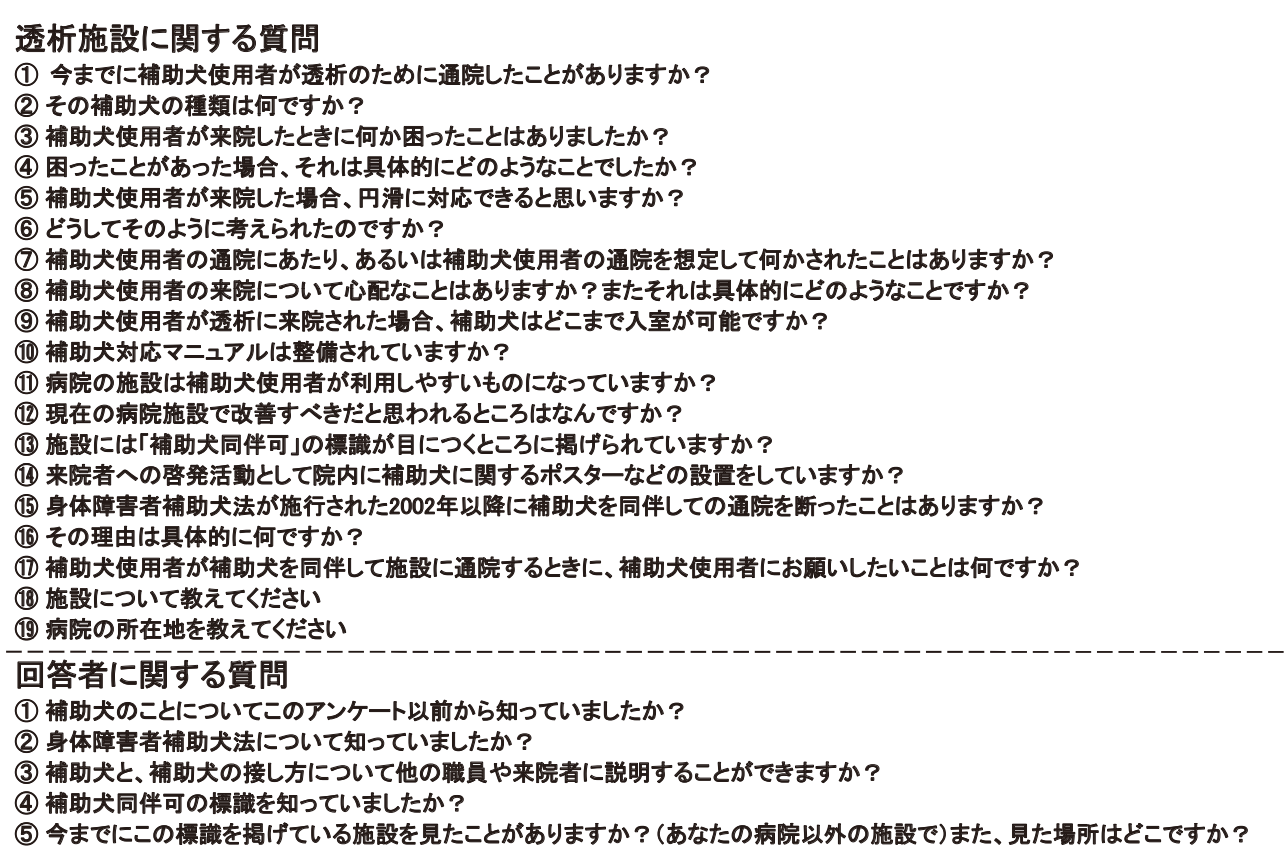

a. 回答があつた透析施設の内訳

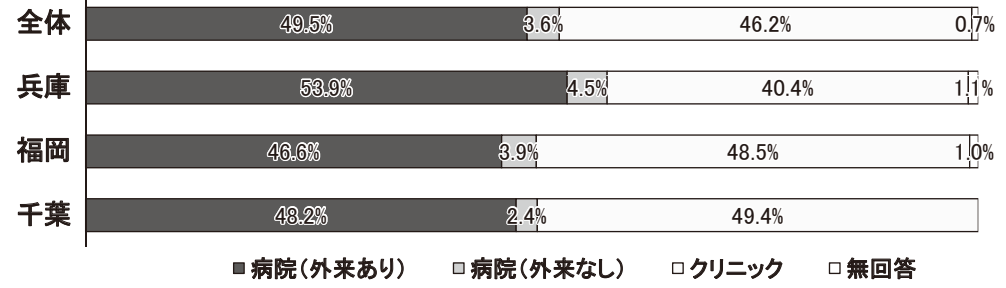

b. 補助犬使用者の来院状況

\begin{tabular}{|c|c|c|}
\hline 全体 3.6\% & $96.0 \%$ & $0.4 \%$ \\
\hline 兵庫 $4.5 \%$ & $94.4 \%$ & 1.11\% \\
\hline 福岡 $1.0 \%$ & $99.0 \%$ & \\
\hline =葉 $5.99 \%$ & $94.1 \%$ & \\
\hline & ロなしロ不明 & \\
\hline
\end{tabular}

c. 来院があった施設の内訳

\begin{tabular}{|l|l|l|l|l|}
\hline & 兵庫 & 福岡 & 千葉 & 全体 \\
\hline 病院 & 0 & 1 & 3 & 4 \\
クリニック & 4 & 0 & 2 & 6 \\
\hline 合計 & 4 & 1 & 5 & 10 \\
\hline
\end{tabular}

図 1 補助犬使用者の透析施設への来院状況

a. 回答があった透析施設の内訳、b. 補助犬使用者の来院状況、c. 来院があった施設の内訳、

d. 来院があった補助犬の種類

アンケートに回答のあった透析施設のうち、全体の $49.5 \%$ (137施設) が外来透析患者を受け入れている病院、 $46.2 \%$ (128施設) が外来透析専門のクリニックであり、 それぞれが全体のほぼ半数ずつを占めた（図 $1 \mathrm{a}$ )。補助 犬使用者が透析のために通院したことがある透析施設は 全体の $3.6 \%$ (10施設) であり (図 $1 \mathrm{~b})$ 、補助犬使用者の 受診経験のない施設が全体の $96.0 \%$ （266 施設）と大部 d. 来院があった補助犬の種類

\begin{tabular}{|l|l|}
\hline 盲導犬 & 10 \\
介助犬 & 0 \\
聴導犬 & 0 \\
\hline 合計 & 10 \\
\hline
\end{tabular}

分を占めていた。施設の種類は、病院が 4 施設（福岡 1 、 千葉 3 )、クリニックが 6 施設 (兵庫 4 、千葉 2 ) で、地域別 では、兵庫 4 施設、福岡 1 施設、千葉 5 施設であった (図 1c）。な打、来院した補助犬の種類は、全て盲導犬であ つた(図1 d)。

3. 透析施設において補助犬を同伴して入室可能な範囲 補助犬が施設内のどこまで入室可能かという質問に対 
補助犬を同伴して入室可能な範囲

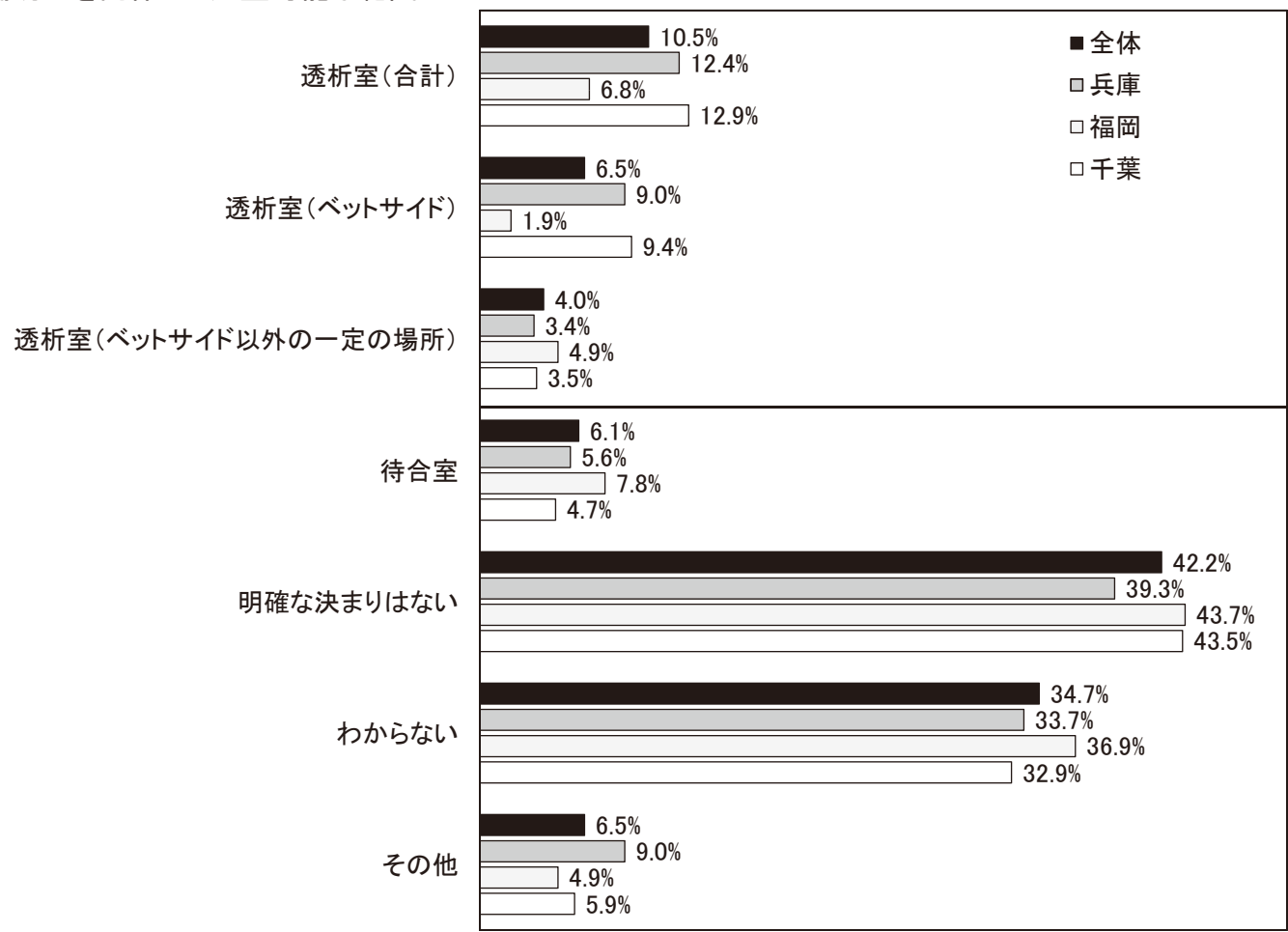

図2 補助犬を同伴して入室可能な範囲

a. 補助犬使用者の来院を想定した準備状況

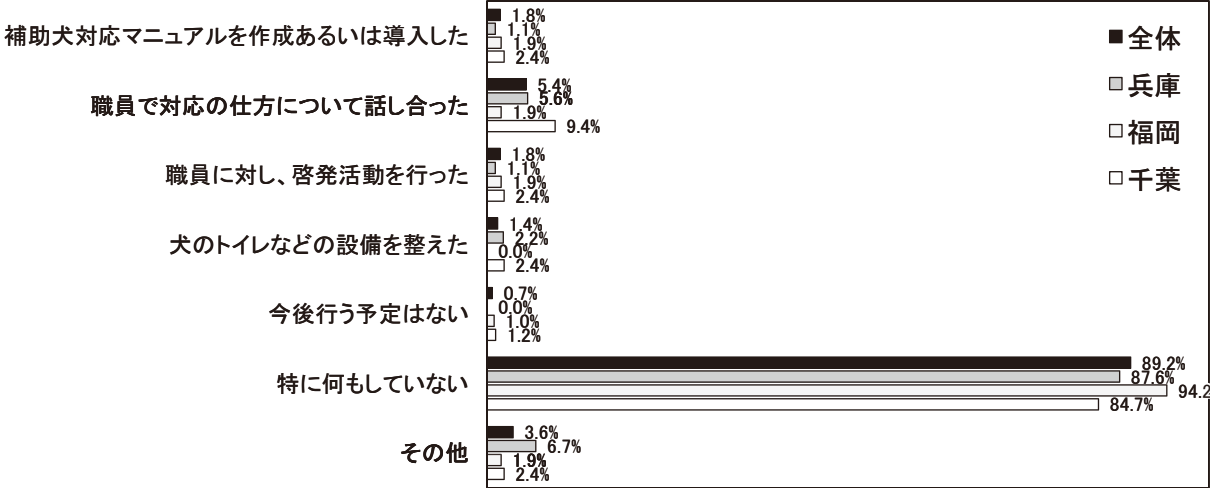

b. 補助犬対応マニュアルの準備状況

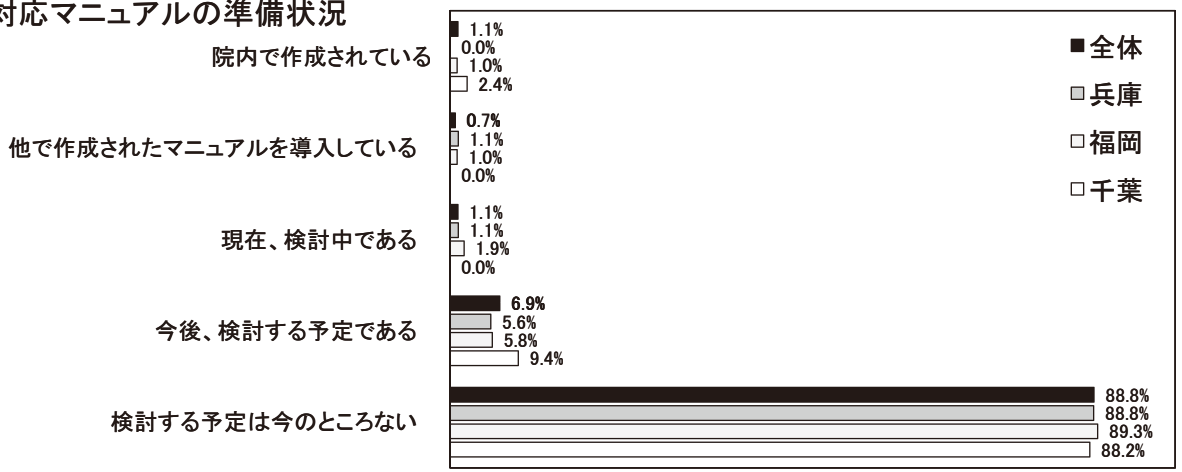

図3透析施設における準備状況

a. 補助犬使用者の来院を想定した準備状況、b. 補助犬対応マニュアルの準備状況

し、透析室内への同伴が可能と回答した施設は $10.5 \%(29$ 施設)であった (図2)。一方、明確な決まりはないと回答 した施設が $42.2 \%$ (117施設) と最も多く、次いで入室可
能範囲についてわからないと回答した施設が $34.7 \%$ (96 施設）で、両者で約 $3 / 4$ を占めた。透析室内への同伴が 可能と回答した施設の $62.1 \%$ (18施設、全体の $6.5 \%)$ 
a. 補助犬同伴可標識の掲示

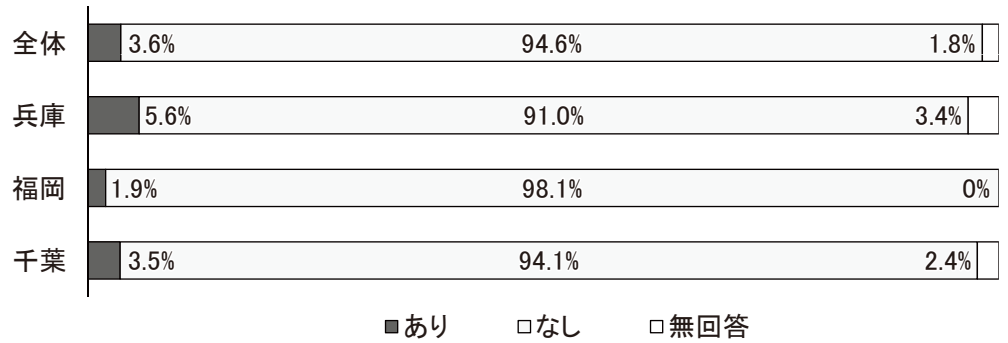

b. 補助犬ポスター掲示等の来院者への啓発活動

\begin{tabular}{|c|c|c|}
\hline $3.6 \%$ & $89.9 \%$ & $5.8 \%$ \\
\hline & & $0.7 \%$ \\
\hline $5.6 \%$ & $86.5 \%$ & \begin{tabular}{|l|}
$6.7 \%$ \\
\end{tabular} \\
\hline & & \\
\hline $0 \%$ & $93.2 \%$ & $\begin{array}{r}0.8 \% \\
0 \%\end{array}$ \\
\hline $5.9 \%$ & $89.4 \%$ & $3.5 \%$ \\
\hline
\end{tabular}

図4透析施設における補助犬の啓発活動

a. 補助犬同伴可標識の掲示、b. 補助犬ポスター提示等の来院者への啓発活動

は透析室内のベッドサイドに、37.9\%（11施設、全体の $4.0 \%$ ）は透析室内のベッドサイド以外の一定の場所に、 それぞれ補助犬の待機場所を設けていた。

なお、補助犬使用者の通院を受け入れた経験のある 10 施設での内訳は、透析室内のベットサイドが 6 施設、待 合室が 1 施設、明確な決まりはないが 2 施設、その他とし て院外と回答した施設が 1 施設であった。

\section{4. 透析施設における補助犬使用者来院への準備状況}

全体の $89.2 \%$ (247施設) と大多数の施設では、補助 犬使用者の通院を想定した準備を特に何もしていなかっ た (図 $3 a$ )。一方で、受け入れ準備として、補助犬対応又 ニュアルを作成あるいは導入した施設は $1.8 \%$ （5施設、 うち 3 施設は受け入れ経験あり)、職員で対応の仕方につ いて話し合った施設は $5.4 \%$ （15施設、うち 7 施設は受 け入れ経験あり)、犬のトイレなどの設備を整えた施設 は $1.4 \%(4$ 施設、うち 3 施設は受け入れ経験あり)であり、 主に補助犬使用者の受け入れを経験している透析施設で 準備が行われていた。

\section{5. 透析施設における補助犬対応マニュアルの準備状況}

補助犬対応マニュアルを作成あるいは導入していた 5 施設 (全体の $1.8 \%$ ) のうち、3 施設では院内でマニュアル を作成し、2施設では他で作成されたマニュアルを導入 していた。6.9\%（19施設）では今後検討する予定であ つたが、 $88.8 \%$ (244施設) と大多数はマニュアルの準備 について検討する予定がなかった（図 $3 b) 。$

\section{6. 透析施設における補助犬の啓発活動}

補助犬同伴可の標識を掲示している透析施設の割合は 全体の $3.6 \%(10$ 施設) であった $($ 図 $4 \mathrm{a})$ 。兵庫では $5.6 \%$ と、 2008 年の兵庫県の病院を対象とした調査の $8.3 \%{ }^{3)}$ 、同 じく 2011 年の $12.4 \%{ }^{4)}$ と比較して、透析施設に打ける 標識の掲示は低い割合に留まっていた。

同様に、補助犬ポスター掲示などの来院者への啓発を 実施している施設は全体の $3.6 \%$ （10施設）のみであつ たが、福岡では 1 施設も行っていなかった (図 $4 \mathrm{~b})$ 。全体 の9割を超える施設ではいずれの揭示も行われていなか つた。

\section{7. 透析施設の医療従事者による補助犬法及び補助犬 の認知度}

回答した透析施設の医療従事者の約半数が補助犬法を 知っていたが、補助犬法の内容まで知っていたのは、全 体の 5.4 \%に過ぎなかった。また、各補助犬について、 盲導犬は全体の $93.1 \%$ が認知していたが、介助犬は 77.3 $\%$ 、聴導犬は $29.6 \%$ であり、 $1.8 \%$ は補助犬について全く 認知していなかった (図 $8 \mathrm{a}$ )。各県での補助犬法及び補 助犬の認知度に、有意な相違は認めなかった。

\section{N. 考察}

補助犬使用者を受け入れている透析施設あるいは症例 の報告は散見されるが $8,9,10)$ 、初めて県単位で実施した 今回の調査の結果、対象となった 3 県には、補助犬使用 者の通院を経験している透析施設が 10 施設あり、同伴さ 
a. 補助犬法の認知度

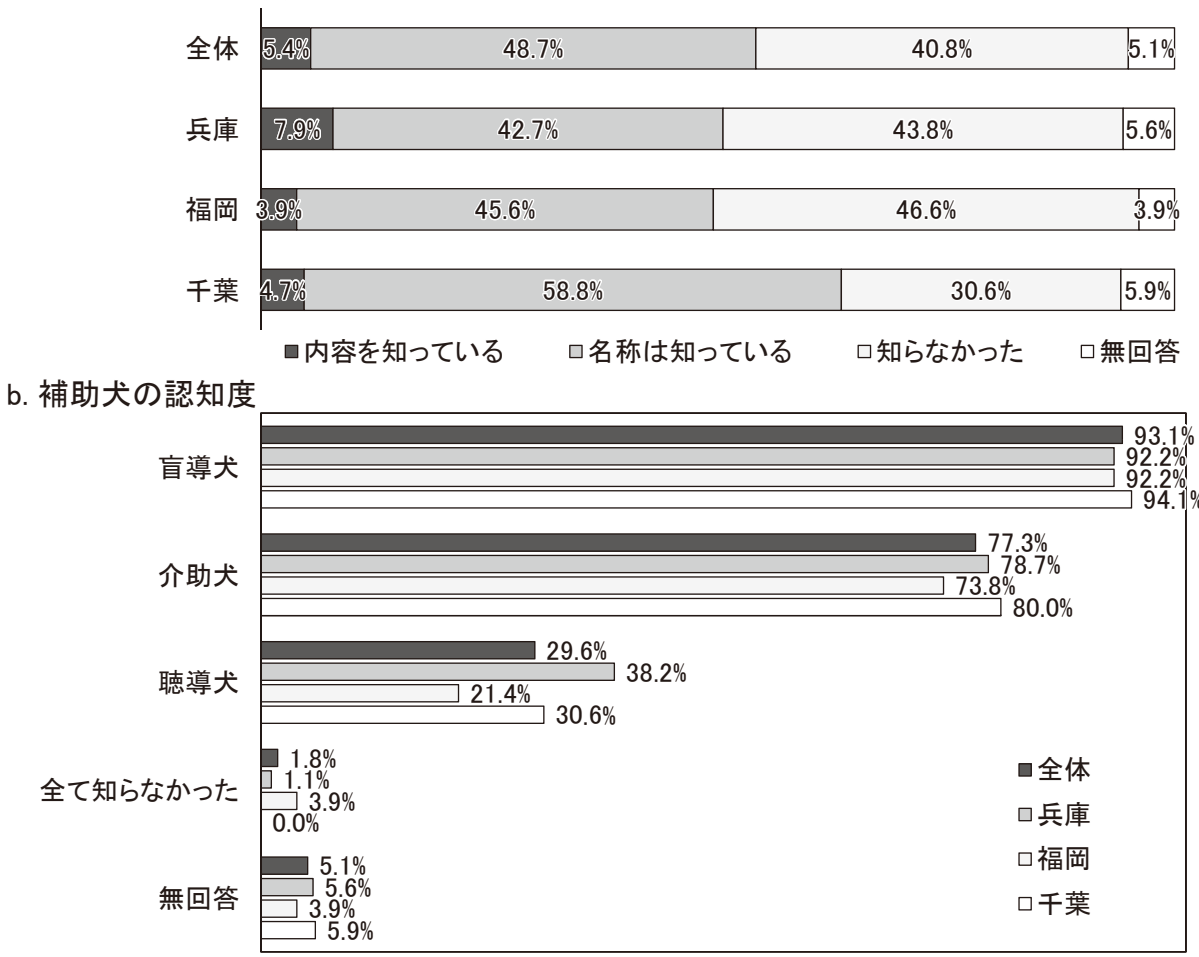

図5 補助犬法及び補助犬の認知度

a. 補助犬法の認知度、b. 補助犬の認知度

れていた補助犬は全て盲導犬であることが新たに明らか になった。この理由としては、介助犬や聴導犬と比較し て盲導犬の頭数が桁違いに多いことと、腎障害と視覚障 害を併発する糖尿病が要因として考えられた。本邦にお いて透析導入の第 1 位の原因疾患である糖尿病は、重大 な合併症として糖尿病性腎症と、糖尿病性網膜症を併発 する11)。前者は慢性腎不全を引き起こすために透析が、 後者は視覚障害を引き起こすために盲導犬が必要となる 場合がある。

通常、人工透析患者は週 3 回、透析施設に通院する必 要があるため、補助犬を同伴することにより通院が自立 できることの意義は、障害者の社会参加の観点からも大 きい。また、通院の道中に加えて、透析を受けている間 にも、補助犬による支援が必要となる事態も生じ得るこ とから、すぐに対応できるように、補助犬が透析べッド のすぐそばで待機できるように待機スペースを準備する ことが望ましい。実際、補助犬を同伴しての通院を受け 入れている 10 施設のうち 6 施設が、透析室内のベットサ イドを補助犬の待機場所としていた。

現在、本邦には約 30 万人の人工透析患者が存在する が ${ }^{11)}$ 、補助犬数が 3 種類合わせて 1,200 頭ほどであるこ とを鑑みると、今回の調查で補助犬使用者の通院を経験 した透析施設が $3.6 \%$ て大、大部分の施設は経験がなかっ たことは妥当な結果と考えられる。他方、透析を受けて
いる補助犬使用者が少なからず存在していることが明ら かになったことから、他の医療機関と同様に透析施設も、 予め、補助犬使用者の受け入れ準備を行って打く必要が ある。

しかし、これまでの病院を対象とした調査と同様に、 透析施設に抢いても、補助犬対応マニュアルの整備を初 め、補助犬使用者受け入れに対して特に何も行っていな いとの回答が大多数を占めた。受け入れ経験がある施設 では準備が行われている割合が高いことから、受け入れ に合わせて準備がされていることも考えられるが、日頃 から、職員と他の施設利用者に補助犬に関して啓発を行 って打くことが、実際に補助犬使用者の来院があった場 合の円滑な対応に繋がるであろう。

ところで、施設内での話し合いや啓発を実施するには、 補助犬対応マニュアルの活用が有用と考えられるが、補 助犬マニュアルを作成あるいは導入している割合は、こ れまでの病院を対象とした調査 ${ }^{4)}$ と同様に低かった。こ のことには、補助犬対応マニュアルの存在が知られてい ないことも理由のひとつと考えられるが、そもそも、盲 導犬こそ大部分の医療従事者が認知しているとは言え、 介助犬、聴導犬については認知度も低く、補助犬法に至 つては未だ認知度が $1 / 2$ 程度と低いために、医療機関が 補助犬を受け入れる義務がある施設であることの認識が 低いことが原因のひとつであろう。 
マニュアルに関しては、自施設でマニュアルを作成し ていた施設もあったが、補助犬対応マニュアルとして、 日本介助犬アカデミーが 2004 年に発行した盲導犬/聴導 犬／介助犬身体障害者補助犬同伴受け入れマニュアル< 医療機関編 $>$ (以下、介助犬アカデミーマニュアル) 10) は、 発行後 9 年が経過しているものの、補助犬および医療に 関する非常に詳細な情報が掲載されており、今日も最初 に参照すべき資料である。これに加えて、近年、補助犬 及び医療機関の所轄官庁である厚生労働省に、公的な補 助犬受け入れマニュアルの整備を求める声が多く届いて いたことから、2013年 6 月に、厚生労働省の社会・援護 局障害保健福祉部が、「身体障害者補助犬ユーザーの受 け入れを円滑にするために〜医療機関に考慮していただ きたいこと〜」(以下、厚労省マニュアル) ${ }^{12)}$ を発行した。 厚労省マニュアルには、具体的な受け入れ事例、職員研 修の方法、他の来院者への情報提供の方法などがわかり やすく記載されており、今後、積極的に活用されるべき 資料であると考えられる。

なお、透析施設は、急患を含む様々な疾患の患者を多 数受け入れている病院とは状況が異なり、定期的に通院 している透析患者がほとんどであり、また施設内の滞在 時間が長い。そのため、他の患者に補助犬について啓発 を実施したり、犬アレルギーを有する患者の状況などを 把握しやすい環境にあると考えられる。このように、透 析施設のみならず、各種医療機関では、その施設の特性 を活かして補助犬使用者の受け入れに当たることが望ま しい。

また、クリニックを対象とした調査は今回が初めてで あったが、クリニックに扎いても病院同様に補助犬を受 け入れていることから、医療機関の規模に関わらず、補 助犬の受け入れは可能であり、クリニックも準備を行う 必要がある。

地域別では、今回調査を行った 3 県は補助犬が比較的 多い地域であり、他の道府県では、補助犬使用者の受け 入れ経験が更にそしいことが予想されることから、補助 犬対応マニュアルなどの資料を活用して、成功事例を参 考に各施設で受け入れ準備を進めておくべきである。

\section{V. 結論}

透析施設は、補助犬を使用している透析患者の高い生 活の質の実現のために、透析ベッドサイドに補助犬を同 伴できる透析環境の整備に努めるべきである。そのため には、衛生的な透析環境の整備はもとより、補助犬対応 マニュアル、補助犬同伴可標識、補助犬啓発ポスターな
どの資料を用いて、施設の特性を活かして、他の医療機 関と同様に、補助犬法に基づく補助犬使用者の円滑な受 け入れのための準備を進める必要がある。

\section{V. 謝辞}

本調査の主旨に同意頂き、アンケート実施にご協力頂 きました兵庫、福岡、千葉の各県の透析施設関係者の皆様 に心から感謝申し上げます。

\section{文献}

1) 厚生労働省 (2009)『ほじょ犬もっと知ってBOOK』厚生労 働省

2) 身体障害者補助犬法の施行状況に関する検討会 (2006) 『身 体障害者補助犬法の施行状況に関する検討会報告書』厚生 労働省

3）三浦靖史, 岡田奈々, 近澤知乃 - 他 (2010) 医療機関にお ける補助犬受け入れの現状と課題. 日本補助犬科学研究, 4 (1) , 31-37.

4）三浦靖史, 大中萌, 石川智昭 (2012) 医療機関に打ける補助 犬受け入れ状沉 : 3 年間での変化と地域差の検討. 日本補助 犬科学研究, 6(1) , 41-48.

5）総務省ホームページ（2010）平成 22 年国勢調查. 総務省 http://www.stat.go.jp/data/kokusei/2010/index.htm\#kekkagai

6) 日本透析医学会 (2010) 2010 年度版日本透析医学会施設会 員名簿.日本透析医学会

7）厚生労働省ホームページ（2012）いろんな場所で会おうね。 ほじょ犬. 厚生労働省 http://www.mhlw.go.jp/topics/bukyoku/ syakai/hojyoken/

8）日本身体障害者補助犬学会第 1 回学術シンポジウム (2007) 透析施設における補助犬の受け入れ. 日本補助犬科学研究 1 (1) , 11-23.

9）キリンファーマ株式会社 (2008)『KIRINPharma and You秋号』 エルゼビア・ジャパン pp.14-15

10）医療機関に打ける補助犬同伴受け入れマニュアル作成委員 会編（2004）『盲導犬/聴導犬/介助犬身体障害者補助犬同 伴受け入れマニュアル<医療機関編 $>$ 』特定非営利活動法人 日本介助犬アカデミー

11）日本透析医学会統計調査委員会 (2011) 『図説わが国の慢性 透析療法の現況 2011年12月31日現在』日本透析医学会p.12

12）厚生労働省社会・援護局障害保健福祉部 (2012)『身体障害 者補助犬ユーザーの受け入れを円滑にするために〜医療機 関に考慮していただきたいこと〜』厚生労働省 